\title{
TESTS FOR THE SELECTION OF FORAGE TURNIP PROGENY TO ORDER THE VIGOR AND LONGEVITY OF SEEDS ${ }^{1}$
}

\author{
SILVIA SANIELLE COSTA DE OLIVEIRA ${ }^{2}$, CIBELE CHALITA MARTINS ${ }^{3}$, FRANCISCO ELDER CARLOS \\ BEZERRA PEREIRA ${ }^{3}$, MARIA TEREZA GOMES LOPES ${ }^{4}$, SALVADOR BARROS TORRES ${ }^{5 *}$
}

\begin{abstract}
Forage turnip (Raphanus sativus L. var. oleiferus Metzg.) progeny with seeds of higher physiological quality are of importance for farmers and seed producing companies. The objective of this work was to identify tests to be used in laboratories for the selection of turnip progeny having seeds of higher germination, vigor, seedling emergence in the field, and storage potential. Seeds of 100 turnip progeny of paternal half-sibs were evaluated as to water content, 1,000-seed mass, first count of the standard germination test, accelerated aging, and seedling emergence in the field. The seeds were subjected to storage for 12 months in unifoliate paper bags kept under room conditions and then evaluated by means of the standard germination test, first count of the standard germination test, and water content. The data were examined as to variance and genetic and phenotypic correlations, heritability, coefficients of genetic variation, and selection gain. The standard germination test, first count of germination, and the accelerated aging test can be used to select forage turnip progeny for seed physiological quality and storage potential. None of the tests used were efficient at selecting progeny with high field emergence.
\end{abstract}

Keywords: Raphanus sativus. Storage. Breeding. Seedling emergence. Vigor tests.

\section{TESTES PARA A SELEÇÃO DE PROGÊNIES DE NABO-FORRAGEIRO VISANDO AO VIGOR E À LONGEVIDADE DAS SEMENTES}

RESUMO - Variedades de nabo-forrageiro (Raphanus sativus L. var. oleiferus Metzg.) com sementes de maior qualidade fisiológica são de interesse para os agricultores e empresas do setor sementeiro. Neste trabalho, o objetivo foi identificar testes passíveis de utilização em laboratório para a seleção de progênies de nabo-forrageiro com sementes de maior germinação, vigor, emergência de plântulas em campo e potencial de armazenamento. Sementes de 100 progênies de meio-irmãos de nabo-forrageiro foram avaliadas quanto ao teor de água, massa de mil sementes, primeira contagem de germinação, germinação, envelhecimento acelerado e emergência de plântulas em campo. As sementes foram armazenadas por 12 meses em sacos de papel unifoliados mantidos em laboratório e avaliadas por meio do teste de germinação, primeira contagem e teor de água. Os dados experimentais foram avaliados quanto à variância e correlações genotípicas e ambientais; herdabilidades; coeficientes de variação genética e ganho por seleção. O teste de germinação, primeira contagem e envelhecimento acelerado podem ser utilizados para a seleção de progênies de nabo-forrageiro visando maior vigor e potencial de armazenamento das sementes. Nenhum dos testes foi eficiente para selecionar progênies visando maior emergência de plântulas em campo.

Palavras-chaves: Raphanus sativus. Armazenamento. Melhoramento. Emergência de plântulas. Testes de Vigor.

\footnotetext{
*Corresponding author

${ }^{1}$ Received for publication in $03 / 08 / 2016$; accepted in 07/29/2016

Paper extracted from the doctoral thesis of the first author.

${ }^{2}$ Instituto Federal Goiano, Iporá, GO, Brazil; silviasanielle@fca.unesp.br.

${ }^{3}$ Department of Crop Production, Universidade Estadual Paulista, Jaboticabal, SP, Brazil; cibele@fcav.unesp.br, eldercarlos12@gmail.com.

${ }^{4}$ Department of Crop and Animal Production, Universidade Federal do Amazonas, Manaus, AM, Brazil; mtglopes@ufam.edu.br.

${ }^{5}$ Department of Plant Science, Universidade Federal Rural do Semi-Árido, Mossoró, RN, Brasil; sbtorres@ufersa.edu.br.
} 


\section{INTRODUCTION}

Programs for the genetic improvement of forage turnip are mostly concerned with the selection of more productive populations as to oil, crop rotation, or animal consumption, adapted to different ecological conditions, thus making possible the incorporation of new areas and higher incomes for the farmer (CARGNELUTTI FILHO et al., 2014; OLIVEIRA et al., 2014). Little attention has been given to the selection of genotypes with seeds of higher physiological quality (OLIVEIRA et al., 2014).

The use of seeds with high germination, vigor, and seedling establishment in the field is of fundamental importance to attain satisfactory economic results. These characteristics are dependent on genotype, line, and progeny with differences among them as to physiological potential and storage potential (MAIA et al., 2011; VASCONCELOS et al., 2012; MARTINS; SILVA; MACHADO, 2014; OLIVEIRA et al., 2014; MAMBRIN et al., 2015).

Aiming to guarantee the quality of seed lots being commercialized, seed companies make use of the results of various laboratory tests that evaluate seed germination and vigor. This information is also used to decide which lots to commercialize first and which to store (CARVALHO; NAKAGAWA, 2012). However, vigor tests may also be used in genetic improvement programs to help in the comparison between lines, varieties, and hybrids as to seed physiological quality (MARCOS-FILHO, 2015; MAMBRIN et al., 2015).

Studies evaluating seed germination and vigor (first count of germination, accelerated aging, seedling emergence in the field, and storage potential) indicated that simple breeding programs combined with methods of selection based on the index theory could be used for the improvement of seed quality (MAIA et al., 2011; VASCONCELOS et al., 2012; MARTINS; SILVA; MACHADO, 2014; OLIVEIRA et al., 2014).

The research works concerned with the genetic improvement of plants with a view to seed physiological quality in bean (MAIA et al., 2011; MAMBRIN et al., 2015), soybean (VASCONCELOS et al., 2012; MARTINS et al., 2016), carrot (MARTINS; SILVA; MACHADO, 2014), and forage turnip (OLIVEIRA et al., 2014) resulted in high heritability values (larger than 70\%) and genetic variability reflecting a favorable situation for the selection for seed physiological potential among plant populations.

It is necessary to emphasize that the research work conducted by Oliveira et al. (2014) showed the efficiency of the first count of germination test, the germination test at temperatures of $20{ }^{\circ} \mathrm{C}$ and 20-35 ${ }^{\circ} \mathrm{C}$, and the accelerated aging test to delineate strategies for the selection of forage turnip populations for seedling emergence in the field under conditions of high temperatures. These tests have the advantage of being faster, more practical, and more economical when compared with the conventional and direct methodology of population selection by means of seedling emergence in the field or after a period of storage (MARTINS; SILVA; MACHADO, 2014; OLIVEIRA et al., 2014).

Thus, the objective of this work was to identify laboratory tests that could be used for the selection of forage turnip progeny with high germination, vigor, field emergence, and storage potential of seeds.

\section{MATERIAL AND METHODS}

The evaluated populations were represented by 100 half-sibs originating from a population of turnip, cultivar 'AL 1000', which was part of the breeding program for oil production of the Plant Production Department of the Faculty of Agronomy, a unit of the Botucatu (SP, Brazil) campus of the Paulista State University (UNESP).

The seeds of each progeny were cleaned and divided in two parts: the first was placed in unifoliate paper bags under room conditions during the determination of the initial seed quality, then stored for a year and the second was first artificially dried up to a water content between $5 \%$ and $7 \%$, then stored in moisture-proof packages and kept at $1{ }^{\circ} \mathrm{C}$ up to the installation of the field emergence test, 8 months later. This last step aimed to maintain the initial level of seed quality (NERY et al., 2014; CARVALHO; NAKAGAWA, 2012). The moisture-proof package was made with impermeable multifoliate walls usually used for the storage and commercialization of Brassicaceae certified seeds (CONTRERAS; FARIAS; NASCIMENTO, 2014), the composition of which is described in Martins, Silva and Machado (2014).

Laboratory tests: initial seed quality was evaluated by the following tests and determinations.

Water content: this test was conducted before the other tests and after the accelerated aging test. Two 7-g samples were each subjected to temperatures of $105 \pm 3{ }^{\circ} \mathrm{C}$ for $24 \mathrm{~h}$ (BRASIL, 2009) and the results expressed in percentage (wet weight).

Mass of 1,000 seeds: based on eight 100-seed samples of each progeny, which were weighed in a $0.0001 \mathrm{~g}$ precision scale (BRASIL, 2009).

Germination test: the germination test was conducted with four 50-seed samples. The seeds were placed on top of two sheets of filter paper, wet with distilled water at an amount corresponding to 2.5 times the weight of the substratum and then put inside transparent plastic boxes $(11.0 \times 11.0 \times 3.5 \mathrm{~cm})$ and taken to a germinator at $20{ }^{\circ} \mathrm{C}$. Seedling counts were made 4 and 10 days after sowing (BRASIL, 2009). 
First count of germination: the number of normal seedlings was determined at 4 days after sowing, as established by the Rules for Testing Seeds (BRASIL, 2009), and the results expressed as an index of vigor.

Accelerated aging test: four grams of seed were spread on top of a screen in plastic boxes with $40 \mathrm{~mL}$ of distilled water (relative humidity of $100 \%$ ) and kept at $41{ }^{\circ} \mathrm{C}$ for $96 \mathrm{~h}$. After that period, the seeds were subjected to the standard germination test and the normal seedlings counted 4 days later (NERY; CARVALHO; GUIMARÃES, 2009).

Seedling emergence in the field: seeds were sown in seed beds inside a screen-walled greenhouse. Sowing took place during the first fortnight of May as recommended (BALBINOT JUNIOR et al., 2009; NICOLOSO et al., 2008). Maximum, mean and minimum temperatures during the period of the seedling emergence in the field were 24,15 , and $10^{\circ} \mathrm{C}$, respectively.

The plots were formed by two $1.5 \mathrm{~m}$ long furrows separated by $0.2 \mathrm{~m}$. In each furrow, 50 seeds were sown at a depth between 2 and $3 \mathrm{~cm}$. The plots were irrigated daily to keep the soil moisture at the appropriate level. Seedling counts were always made at the same time of the day during 12 days after sowing. At the end of that period, the percentage of seedling emergence was calculated (OLIVEIRA et al., 2014). Concomitantly with this, seedling speed of emergence (IVE) was calculated on the basis of the formula proposed by Maguire (1962).

Seed storage potential: the seeds, which were kept in multifoliate paper bags under room conditions, were evaluated at 6 and 12 months of storage by means of the first count of germination test, germination, and water content. Air temperature and relative humidity of the environment were registered.

Treatment replications were distributed according to a completely random design with four replications. The experimental data were subjected to analysis of variance and covariance. The following parameters were evaluated: phenotypic and genotypic variances between lineage means, mean environmental variance, large sense heritability based on plot means, genetic coefficient of variation, and phenotypic, genotypic, and environment correlations. After calculation of these parameters, the genetic gain per selection with an intensity of $20 \%$ was calculated. This is considered a standard index and also a function of the population sample size (OLIVEIRA et al., 2014).

\section{RESULTS AND DISCUSSION}

The mean seed water content of the progeny was $4.5 \pm 1.5 \%$. This value is within the limits recommended for the storage of orthodox seeds and of Brassicaceae for medium to long periods of time (CARVALHO; NAKAGAWA, 2012; CONTRERAS; FARIAS; NASCIMENTO, 2014). The results of seed water content may be considered relatively uniform and this is important because water content affects seed metabolic activity and seed water content uniformity is a primordial factor for the standardization of the evaluations as to physiological quality (MORAIS; ROSSETTO, 2013) as well as the mass of 1,000 seeds (BRASIL, 2009).

Following seed accelerated aging, the water content of the progeny seeds was found to be between $28 \%$ and $47 \%$, that is, a relatively high variation. On the other hand, it is necessary to consider that this research compared the seeds of half-sib (genetically different) progeny and some characteristics that differ among genotypes may influence the water absorption process such as seed size, tegument permeability, and chemical composition (CARVALHO; NAKAGAWA, 2012; MARTINS; SILVA; MACHADO, 2014).

So, the variation of up to 19 percentage points found when seed water content was measured after the seed aging procedure was similar to those reported by Oliveira et al. (2014) in different progeny of forage turnip and 7 percentage points higher than the values reported with carrot seeds (MARTINS; SILVA; MACHADO, 2014).

After the storage periods of 6 and 12 months, it was verified that the storage conditions were adequate to maintain the seeds' physiological quality as the seeds showed water contents of $7.0 \pm 2.8 \%$ to $4.9 \pm 1.9 \%$, respectively, that is, within the limits indicated for medium to long storage periods (CARVALHO; NAKAGAWA, 2012; CONTRERAS; FARIAS; NASCIMENTO, 2014).

On the other hand, this increment in water content after 6 months of storage, followed by a reduction after 12 months of storage, permits us to infer that the multifoliate package used for the commercialization of vegetable seeds may be classified as semipermeable as proposed (CONTRERAS; FARIAS; NASCIMENTO, 2014; MARTINS; SILVA; MACHADO, 2014), because the highest mean water content was verified after exposure of the seeds to the highest relative humidity after 6 months of storage (Figure 1). Notwithstanding the mean temperature of $22 \pm 3{ }^{\circ} \mathrm{C}$ and mean relative humidity of $45 \pm 15 \%$ found to occur during the storage period, these are conditions that may be considered favorable for maintaining seed physiological quality under uncontrolled environmental conditions (CARVALHO; NAKAGAWA, 2012). 

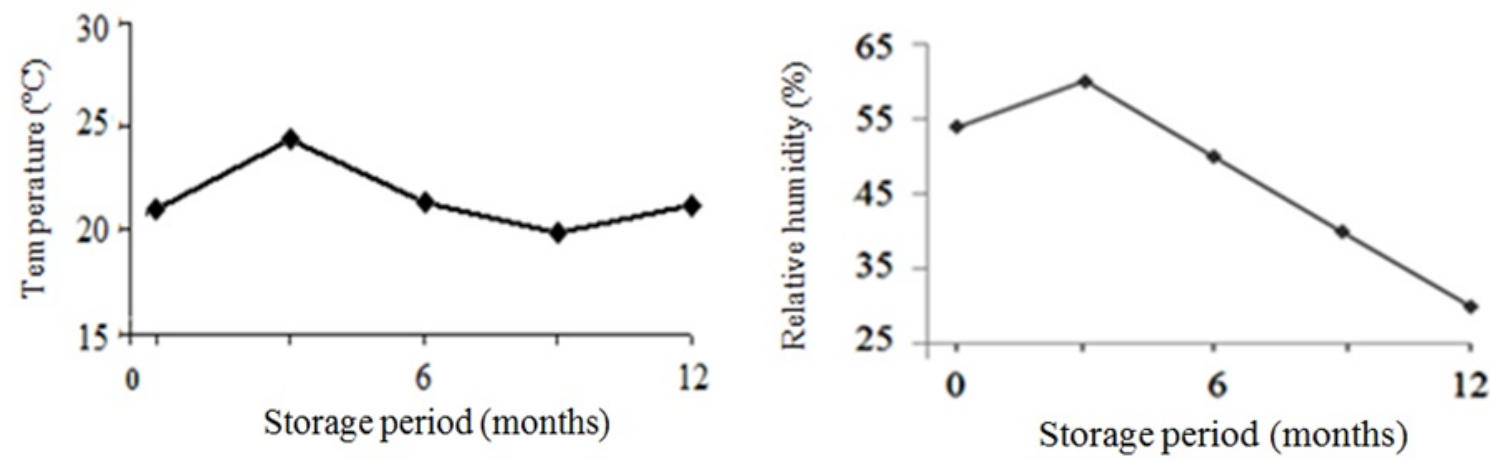

Figure 1. Air temperature and relative humidity during the seed storage period under laboratory environmental conditions.

The seeds of the forage turnip progeny showed significant differences for all evaluated characteristics (Table 1), thus suggesting that there is genetic variability among progeny. So there is a possibility of gains with the selection for all of the evaluated characters that are related to seed physiological quality such as 1000-seed weight, germination, seedling emergence in the field, vigor, and storage potential.

Table 1. Summary of the analysis of variance and estimation of the genetic parameters for the tests of evaluation of seed physiological quality of 100 half-brother forage turnip progenies.

\begin{tabular}{|c|c|c|c|c|c|c|c|c|c|c|c|}
\hline \multirow{4}{*}{ F. V. } & \multirow{4}{*}{ G.L } & \multicolumn{10}{|c|}{ Mean square } \\
\hline & & \multirow{3}{*}{ MMS } & \multirow{3}{*}{$\begin{array}{c}\mathrm{FC} \\
0 \text { months }\end{array}$} & \multirow{3}{*}{$\begin{array}{c}\mathrm{G} \\
0 \\
\text { months }\end{array}$} & \multirow{3}{*}{$\mathrm{EC}$} & \multirow{3}{*}{ IVE } & \multirow{3}{*}{ EA } & \multicolumn{4}{|c|}{ Storage (months) } \\
\hline & & & & & & & & \multicolumn{2}{|c|}{6} & \multicolumn{2}{|c|}{12} \\
\hline & & & & & & & & $\mathrm{FC}$ & G & $\mathrm{FC}$ & G \\
\hline Progenies & 99 & $4.2^{*}$ & $124.3^{*}$ & $457.9^{*}$ & $277.3^{*}$ & $4.8^{*}$ & $1813.5^{*}$ & $288.2^{*}$ & $195.3^{*}$ & $327.7^{*}$ & 393.6 \\
\hline Residue & 300 & 0.4 & 40.3 & 45.0 & 47.9 & 0.2 & 162.1 & 80.2 & 68.5 & 86.5 & 98.0 \\
\hline Mean & & 9.4 & 79.1 & 81.1 & 91.6 & 4.7 & 35.6 & 48.6 & 80.3 & 42.7 & 71.9 \\
\hline$h^{2}$ & & 90.7 & 67.6 & 90.2 & 82.7 & 95.5 & 91.1 & 72.2 & 64.9 & 73.6 & 75.1 \\
\hline $\mathrm{CVg}$ & & 10.4 & 4.9 & 12.5 & 8.3 & 22.7 & 57.0 & 14.8 & 7.0 & 18.2 & 12.0 \\
\hline $\mathrm{CVe}$ & & 6.6 & 6.7 & 8.3 & 7.6 & 9.8 & 35.7 & 18.4 & 10.3 & 21.8 & 13.8 \\
\hline $\mathrm{CVg} / \mathrm{CVe}$ & & 1.6 & 0.7 & 1.5 & 1.1 & 2.3 & 1.6 & 0.8 & 0.7 & 0.8 & 0.9 \\
\hline
\end{tabular}

${ }^{1}$ Source of variation (FV); 1,000 seeds mass (MMS, g); first count of germination (FC, \%), germination (G, \%), seedling emergence in the field (EC, \%) seedling speed of emergence in the field index (IVE), accelerated aging (EA, \%).

*Significant at the level of $1 \%$ of probability according to the F test; heritability (\%); CVe - coefficient of experimental variation; $\mathrm{CVg}$ - coefficient of genetic variation.

The heritability coefficients reflected a favorable situation for selection as they varied between $64.9 \%$ and $95.5 \%$. Similar results were reported for seeds of forage turnip half-sibs for the test of germination carried under two temperatures, accelerated aging, and seedling emergence under conditions of high temperatures (OLIVEIRA et al., 2014). High heritability estimations were also reported by Silva, Vieira, and Nascimento (2010) with carrot (77\%), and Martins et al. (2016) with soybean $(96 \%)$ seeds. The main function of heritability in genetic studies is its predictive role, expressing the degree of confidence of the phenotypic value as an indication of the genetic value, or the degree of correlation between the phenotypic and genotypic values (MELO et al., 2009).

Values close to or larger than the units $(0.7$ to 2.3) found in the ratio $\mathrm{CVg} / \mathrm{CVe}$ (genetic and experimental variation) in this research work with forage turnip seed are superior to the environmental one and indicate that the existing variability would be of genetic origin and that the situation is also favorable to selection (CRUZ; REGAZZI; CARNEIRO, 2012). A high $\mathrm{CVg} / \mathrm{CVe}$ (1.03) was also reported in a study with carrot seeds (SILVA; VIEIRA; NASCIMENTO, 2010).

The high genetic variability for the characteristics related to the seeds is a consequence of the small importance that has been given to the 
theme in plant breeding programs that have had, as their main purpose, yield and adaptation (MAIA et al., 2011; VASCONCELOS et al., 2012; MARTINS; SILVA; MACHADO, 2014; OLIVEIRA et al., 2014). The genetic variability of the evaluated characters indicated that forage turnip breeding procedures may contribute to significant improvement in seed physiological quality.
Positive and significant genotypic correlations were observed for the germination, vigor (first count of germination, and accelerated aging) and storage potential characters, that is, the improvement of a given character will bring about simultaneous increment in the correlated characters (Table 2).

Table 2. Estimations of the coefficient of genetic and environmental correlations ( $\mathrm{rg}$ - above the diagonal; ra - below the diagonal ) among the characters of 1,000 seed mass (MMS, g), first count of germination (FC, \%), germination (G, \%), seedling field emergence (EC, \%), seedling emergence in the field index (IVE), accelerated aging (EA, \%), first count of germination after six and 12 months of storage of seeds of 100 half-brothers of forage turnip progenies.

\begin{tabular}{|c|c|c|c|c|c|c|c|c|c|c|}
\hline Characters & MMS & $\begin{array}{c}\mathrm{FC} \\
0 \\
\text { months } \\
\end{array}$ & $\begin{array}{c}\mathrm{G} \\
0 \\
\text { months }\end{array}$ & EC & IVE & $\overline{E A}$ & $\begin{array}{c}\mathrm{FC} \\
6 \\
\text { months }\end{array}$ & $\begin{array}{c}\mathrm{G} \\
6 \\
\text { months }\end{array}$ & $\begin{array}{c}\mathrm{FC} \\
12 \\
\text { months }\end{array}$ & $\begin{array}{c}\mathrm{G} \\
12 \\
\text { months }\end{array}$ \\
\hline MMS & - & 0.03 & -0.05 & -0.12 & -0.01 & -0.08 & 0.12 & -0.07 & 0.00 & -0.02 \\
\hline $\begin{array}{l}\mathrm{FC} \\
\text { (0 months) }\end{array}$ & $0.53^{* *}$ & - & $0.95^{* *}$ & -0.02 & -0.06 & $0.31^{* *}$ & 0.13 & $0.43^{* *}$ & 0.19 & $0.33^{* *}$ \\
\hline $\begin{array}{l}\mathrm{G} \\
\text { (0 months) }\end{array}$ & $0.60^{* *}$ & $0.90^{* *}$ & - & 0.02 & 0.04 & $0.34^{* *}$ & 0.14 & $0.38^{* *}$ & 0.24 & $0.33^{* *}$ \\
\hline EC & $0.49^{* *}$ & $0.43^{* *}$ & $0.49^{* *}$ & - & $0.90^{* *}$ & -0.03 & 0.06 & -0.07 & 0.03 & -0.13 \\
\hline IVE & $0.38^{* *}$ & $0.35^{* *}$ & $0.37^{* *}$ & $0.78^{* *}$ & - & -0.08 & -0.01 & -0.08 & -0.02 & -0.14 \\
\hline EA & 0.14 & 0.12 & 0.14 & 0.17 & 0.10 & - & -0.15 & 0.23 & -0.01 & $0.29^{* * *}$ \\
\hline $\begin{array}{l}\text { FC } \\
\text { (6 months) }\end{array}$ & $0.27^{* *}$ & 0.14 & 0.19 & 0.17 & 0.18 & 0.14 & - & $0.63^{* *}$ & $0.76^{* *}$ & $0.48^{* *}$ \\
\hline $\begin{array}{l}\text { G } \\
\text { (6 months) }\end{array}$ & $0.38^{* *}$ & $0.35^{* *}$ & $0.46^{* *}$ & $0.32^{* *}$ & 0.25 & 0.13 & $0.39^{* *}$ & - & $0.65^{* *}$ & $0.82^{* *}$ \\
\hline $\begin{array}{l}\mathrm{FC} \\
\text { (12 months) }\end{array}$ & 0.15 & 0.22 & 0.17 & 0.13 & 0.11 & -0.03 & 0.04 & 0.24 & - & $0.75^{* *}$ \\
\hline $\begin{array}{l}G \\
\text { (12months) }\end{array}$ & $0.29^{* *}$ & 0.23 & $0.27^{* *}$ & 0.21 & 0.15 & 0.02 & 0.25 & 0.54 & $0.66^{* *}$ & - \\
\hline
\end{tabular}

${ }^{* *}$ Significant at the level of $1 \%$ of probability, according to the $\mathrm{F}$ test.

On the other hand, none of the tests was efficient to select progeny with higher seedling emergence in the field, for, with the exception of the positive correlation between this character and that of seedling speed of emergence in the field index, no other one was verified. The genetic and positive correlations verified among these field tests, as have been identified in others, such as first count of germination and germination (after 6 and 12 months of storage) would have no genetic meaning in this research work due to the fact that they were conducted simultaneously, in conjunction, so that the results are interrelated due to the methodology used. In addition to that, the tests did not allow the anticipation of time for the selection of the progeny, if compared to the others.

Thus, the germination, first count of germination, and accelerated aging tests can be applied in breeding programs with a view to the selection of forage turnip progeny of higher seed physiological quality with good results for seed-producing companies. These tests give quick answers in the selection of long-lived seeds permitting a considerable reduction in the period of time needed for genotype selection, mainly when the storage period considered is 12 months. They permit the selection of progeny in periods of time of 4 to 10 days, depending on the adopted test. In addition to that, these tests are practical and of low cost because the material and personnel they demand are those in everyday use in laboratories (NERY; CARVALHO; GUIMARÃES, 2009).

The genetic gains estimations $(\%)$ and the initial mean population ( $\mu$ i), of the selected population $(\mu \mathrm{s})$ and the improved one $(\mu \mathrm{m})$ are shown in Table 3. The adoption of this procedure permitted us to attain selection gains for all evaluated characters. The less expressive gains were for the first count of germination and the seedling emergence in the field tests, that is, between $2 \%$ and $3 \%$.

Twelve months of storage were highly promising. The initial means of those characters were approximately 81,36 , and $72 \%$. After the selection improved, estimated means were 98, 63, and $84 \%$. It is thus important to emphasize that the selection of the 20 best progeny $(20 \%$ of the population) made possible the expressive and significant gains of $20.33,77.41$, and $16.73 \%$. The speed of emergence index was another character that showed a high estimated genetic gain (32.28\%). But, this character would need a direct selection based on the character itself because no positive genotypic correlations with the other characters were verified according to the indexes theory (Table 3 ). 
Table 3. Estimations of mean genetic gains per selection (GS), and in percentage (\%), germination (G, \%), and population means of the tests to evaluate the physiological quality of seeds of 100 progenies of forage turnip half-brothers.

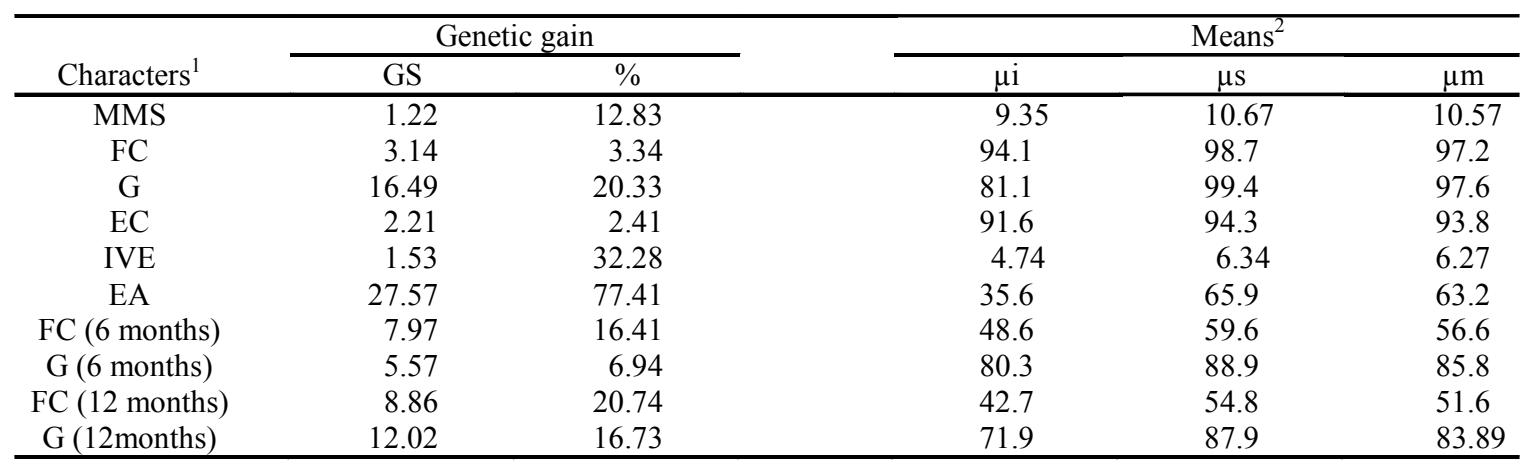

${ }^{1} 1,000$ seeds mass (MMS), first count of germination (FC, \%), germination $(\mathrm{G}, \%)$, seedling emergence in the field (EC, \%), seedling speed of emergence in the field index (IVE), accelerated aging (EA, \%).

${ }^{2}$ Population initial means $(\mu \mathrm{i})$, selected genotypes $(\mu \mathrm{s})$, and mean of the improved population $(\mu \mathrm{m})$.

All of those characters should be highlighted in the selection process because they are representative of seed quality. Germination capacity is the main seed attribute and the results of this test are used to compare seed lots, to determine sowing rate, and to approve lots for commercialization (CARVALHO; NAKAGAWA, 2012). In the case of the accelerated aging test, it can be considered as an efficient test mainly for the selection of lots with longer storability (NERY; CARVALHO; GUIMARÃES, 2009). Seed storage is a fundamental procedure for the maintenance of seed physiological quality and guaranteed vigor and viability during the period that goes from seed harvesting to seed sowing (CARVALHO; NAKAGAWA, 2012).

Therefore, the continuity of this breeding program will permit the attainment of forage turnip seeds with superior seed physiological quality, that is, higher germination, vigor, and longevity under storage conditions, thus benefiting seed companies and farmers.

\section{CONCLUSIONS}

The standard germination test, the first count of germination, and the accelerated aging tests may be used for the selection of forage turnip progeny for seed physiological quality and storage potential.

None of the aforementioned tests were efficient at selecting for higher seedling emergence in the field.

\section{REFERENCES}

BALBINOT JUNIOR, A. A. et al. Desempenho da cultura do feijão após diferentes formas de uso do solo no inverno. Ciência Rural, Santa Maria, v. 39, n. 8, p. 2340-2346, 2009.

BRASIL. Ministério da Agricultura, Pecuária e
Abastecimento. Regras para análise de sementes. Secretaria de Defesa Agropecuária. Brasília: MAPA/ ACS, 2009. 399 p.

CARGNELUTTI FILHO, A. et al. Relações lineares entre caracteres de nabo forrageiro e de tremoço branco. Ciência Rural, Santa Maria, v. 44, n. 1, p. 18-24, 2014.

CARVALHO, N. M.; NAKAGAWA, J. Sementes: ciência, tecnologia e produção. 5. ed. Jaboticabal, SP: FUNEP, 2012. 590 p.

CONTRERAS, S.; FARIAS, A.; NASCIMENTO, W. M. Produção de sementes de Brassica oleraceae. In: NASCIMENTO, W. M. (Ed.). Produção de sementes de hortaliças. Brasília: Embrapa Hortaliças, 2014. v. 1, p. 45-73.

CRUZ, C. D.; REGAZZI, A. J.; CARNEIRO, P. C. $\mathrm{S}$. Modelos biométricos aplicados ao melhoramento genético. 4. ed. Viçosa, MG: UFV, 2012. v. 1. 514 p.

MAGUIRE, J. D. Speed of germination-aid in selection and evaluation for seedling emergence and vigor. Crop Science, Madison, v. 2, n. 1, p. 176-177, 1962.

MAIA, L. G. S. et al. Variabilidade genética associada à germinação e vigor de sementes de linhagens de feijoeiro comum. Ciência e Agrotecnologia, Lavras, v. 35, n. 2, p. 361-367, 2011.

MAMBRIN, R. B. et al. Seleção de linhagens de feijão com base no padrão e na qualidade de sementes. Revista Caatinga, Mossoró, v. 28, n. 3, p. 147-156, 2015.

MARCOS FILHO, J. Fisiologia de sementes de plantas cultivadas. 2. ed. Londrina, PR: ABRATES, 
2015. $660 \mathrm{p}$.

MARTINS, C. C. et al. Metodologia para seleção de linhagens de soja visando germinação, vigor e emergência em campo. Revista Ciência Agronômica, Fortaleza, v. 47, n. 3, p. 455-461, 2016.

MARTINS, C. C.; SILVA, N.; MACHADO, C. G. Testes para a seleção de populações de cenoura visando ao vigor e à longevidade das sementes. Ciência Rural, Santa Maria, v. 44, n. 5, p. 768-775, 2014.

MELO, R. A. et al. Variabilidade genética em progênies de meios-irmãos de coentro. Horticultura Brasileira, Brasília, v. 27, n. 3, p. 325-329, 2009.

MORAIS, C. S. B.; ROSSETTO, C. A. V. Testes de deterioração controlada e envelhecimento acelerado para avaliação do vigor em nabo forrageiro. Revista Ciência Agronômica, Fortaleza, v. 44, n. 4, p. 703-713, 2013.

NERY, M. C.; CARVALHO, M. L. M.; GUIMARÃES, R. M. Teste de vigor para avaliação da qualidade de sementes de nabo-forrageiro. Informativo Abrates, Londrina, v. 19, n. 1, p. 448, 2009.

NERY, M. C. et al. Harvesting, processing and quality control of oil radish seeds. Journal of Seed Science, Pelotas, v. 36, n. 2, p. 143-153, 2014.

NICOLOSO, R. S. et al. Eficiência da escarificação mecânica e biológica na melhoria dos atributos físicos de um latossolo muito argiloso e no incremento do rendimento de soja. Revista Brasileira de Ciência do Solo, Viçosa, v. 32, n. 4, p. 1723-1734, 2008.

OLIVEIRA, S. S. C. et al. Seleção de progênies de nabo-forrageiro para germinação sob altas temperaturas. Ciência Rural, Santa Maria, v. 44, n. 2, p.217-222, 2014.

SILVA, G. O.; VIEIRA, J. V.; NASCIMENTO, W. M. Estratégias de seleção para germinação de sementes de cenoura em alta temperatura. Revista Ceres, Viçosa, v. 57, n. 1, p. 60-65, 2010.

VASCONCELOS, E. S. et al. Estimativas de parâmetros genéticos da qualidade fisiológica de sementes de genótipos de soja produzidas em diferentes regiões de Minas Gerais. Semina: Ciências Agrárias, Londrina, v. 33, n. 1, p. 65-76, 2012. 